Chapman University

Chapman University Digital Commons

Philosophy Faculty Articles and Research

Philosophy

Winter 2019

\title{
Self-Ownership as Personal Sovereignty
}

John Thrasher

Follow this and additional works at: https://digitalcommons.chapman.edu/philosophy_articles

Part of the Ethics and Political Philosophy Commons, and the Other Philosophy Commons 


\section{Self-Ownership as Personal Sovereignty}

\section{Comments}

This is a pre-copy-editing, author-produced PDF of an article accepted for publication in Social Philosophy \& Policy, volume 36, issue 2, in 2019 following peer review. The definitive publisher-authenticated version is available online at https://doi.org/10.1017/S0265052519000396

\section{Copyright}

Social Philosophy and Policy Foundation 


\title{
SELF-OWNERSHIP AS PERSONAL SOVEREIGNTY
}

\author{
BY JOHN THRASHER
}

\begin{abstract}
Self-ownership has fallen out of favor as a core moral and political concept. I argue that this is because the most popular conception of self-ownership, what I call the property conception, is typically linked to a libertarian (of the left or right) political program. Seeing self-ownership and libertarianism as being necessarily linked leads those who are not inclined toward libertarianism to reject the idea of selfownership altogether. This, I argue, is mistaken. Self-ownership is a crucial moral and political concept that can earn its keep if we understand it not as type of property right in the self, but rather as a set of territorial rights one has over one's body. This territorial conception of self-ownership, which I call the sovereignty conception of self-ownership avoids the traditional arguments raised against the property conception of self-ownership and has other benefits besides. Accepting this conception of self-ownership, I argue, has considerable moral and political benefits without taking on the costs associated with other forms of self-ownership.
\end{abstract}

KEY WORDS: sovereignty, rights, libertarianism, property, ownership, autonomy

That no man is good enough to govern another man without that other's consent. I say this is the leading principle, the sheet-anchor of American republicanism ... Now the relation of master and slave is pro tanto a total violation of this principle. The master not only governs the slave without his consent, but he governs him by a set of rules altogether different from those which he prescribes for himself. Allow ALL the governed an equal voice in the government, and that, and that only, is self-government.

--Abraham Lincoln, 1865

The great fact underlying the claim for universal suffrage is that every man is himself and belongs to himself, and represents his own individuality, not only in form and features, but in thought and feeling. And the same is true of woman. She is herself, and can be nobody else than herself. Her selfhood is as perfect and as absolute as is the selfhood of man.

--Frederick Douglas, 1886

Self-ownership has fallen out of favor among mainstream contemporary moral and political theorists. It has been abandoned to the libertarians, who are alone interested 
in defending it as a core normative concept. Liberals are keen to disassociate themselves from the idea ${ }^{1}$ as are egalitarians. ${ }^{2}$ There are good historical reasons for this. Modern liberalism in either its Rawlsian ${ }^{3}$ or perfectionist ${ }^{4}$ guise, has no use for the idea. Even liberal theories that embrace a robust defense of market institutions ${ }^{5}$ do so without invoking a basic right to self-ownership. Libertarians of the left ${ }^{6}$ and right $^{7}$ embrace a strong conception of self-ownership, but many have questioned how "liberal" these views really are, since they seem to prioritize ownership and property rights over freedom and equality as such. ${ }^{8}$ The charge that libertarians care more about property than freedom is an old one, but one that still has purchase.

From this skepticism about self-ownership, this essay argues that the conception of self-ownership put forward by its libertarian defenders and liberal critics is both overly expansive and unmoored from the basic concerns that generate the need for the concept in the first place. Because of this, we should replace what I call the property conception (defended primarily by libertarians) with what I call sovereignty conception of selfownership. The basic idea of thinking about self-ownership as sovereignty is that the body provides a natural basis for something like a system of individual territorial rights. The individual is sovereign with regard to the body like the monarch or assembly is sovereign over its territory. This change of focus away from thinking of self-ownership as property to thinking of it as a form of sovereignty has interesting implications for how to understand the rights associated with self-ownership. It captures the core intuitive moral idea at the heart of self-ownership, without requiring certain claims about the acquisition or ownership of private property. It does this by thinking of self-ownership as a bundle of territorial rights, rather than as a type of property rights over the self. What is distinctive 
about self-ownership rights, on this view, is that they protect the sovereignty of the individual's body and actions.

Liberals and libertarians should endorse the sovereignty conception of selfownership, I argue, because it explains foundational claims about the freedom and equality of individuals better than the relevant alternatives. It also provides an empirically plausible and conceptually parsimonious way of generating basic liberal rights. The attractiveness of the sovereignty conception of self-ownership for liberals is based on the relative cost to most moral and political conceptual schemes of including self-ownership. There is very little cost to these schemes in ability to answer basic moral and political questions, but there is a significant benefit in that self-ownership accords well with many deeply held basic moral and political principles. The cost associated with self-ownership is in its denial, not in its acceptance.

\section{What We Talk About When We Talk About Self-Ownership}

Since the publication of Robert Nozick's Anarchy, State, and Utopia, debates about self-ownership have often been proxy wars of competing ideologies. Instead of trying to understand or analyze the idea of self-ownership, the basic contours of the concept have been largely assumed and then used to defend or attack various substantive political positions. A right to self-ownership will inevitably have political implications, but the political implications of self-ownership should not be our main reason for thinking that it is worth including in our moral and political conceptual scheme. The commitments of our political theories are justified by reference to basic political concepts 
like LIBERTY, EQUALITY, WELFARE, and, perhaps, SELF-OWNERSHIP. We need to know the details of any particular conception of self-ownership to know its exact political implications, but it is pretty clear that most discussions of self-ownership are ultimately concerned with the relationship between self-ownership, private property, and legitimate government authority, not with understanding self-ownership as such.

This is not surprising once we reflect on the fact that the contemporary idea of self-ownership comes from one of its most relentless critics: G. A. Cohen. Seeing selfownership at the heart of Nozick's defense of libertarianism, Cohen ${ }^{9}$ characterizes selfownership as the "fullest right a person (logically) can have over herself provided that each other person also has just such a right.” The conclusion Cohen draws is that selfownership imposes extreme limits on legitimate government authority. What "fullest right" means here is underspecified, but it seems to include strong liberty rights to action as well as strong powers to acquire and use property. Elsewhere, Cohen ${ }^{10}$ is more explicit about self-ownership, arguing it is the claim that:

Each person is the morally rightful owner of himself. He possesses over himself, as a matter of moral right, all those rights a slaveholder has over a complete chattel slave as a matter of legal right, and he is entitled, morally speaking, to dispose over himself in the way a slaveholder is entitled, legally speaking, to dispose over his slave.

This idea is, according to Cohen, at the heart of Nozick's defense of libertarianism, with the ultimate inspiration arising from Locke's discussion of property in Chapter 5, §27 of 
The Second Treatise of Government. There are important puzzles about acquisition on this broadly Lockean account of property, ${ }^{11}$ but the key point relevant to self-ownership is Locke's claim that it is possible to extend the original ownership in one's self to external objects, legitimately removing them from the commons. This basic argumentative strategy forges a natural link between the idea of self-ownership, private property, and the scope of legitimate government authority. Call this idea the scope thesis about self-ownership.

Scope Thesis: Self-Ownership justifies strong individual property rights, which severely limit the scope of legitimate government action.

It is the scope thesis that is at stake in most contemporary debates about self-ownership. Notice that the thesis is not, strictly speaking, about self-ownership at all, but rather about the downstream political implications of self-ownership.

The scope thesis relies on two further ideas. The first is the extension claim that self-ownership rights can be legitimately extended to external objects. The extension of self-ownership rights to external objects creates natural rights to property; which governments cannot legitimately infringe without thereby assailing one's self-ownership rights. The second is the stringency claim that property rights are as morally serious as the underlying right to self-ownership. It is possible to accept the extension claim, while rejecting the stringency claim (or vice versa) and to, thereby, reject the scope thesis as a whole. Judith Thomson's ${ }^{12}$ rejection of the scope thesis, as Nozick presents it, seems to be a rejection of the stringency claim, for instance. ${ }^{13}$ 
The scope thesis is common currency in philosophical discussions of selfownership, despite the fact that it is not directly a thesis about the nature of selfownership. Rather, it is a thesis about the relationship between self-ownership, property, and political authority. It has become natural to equate the idea of self-ownership with its political implications in the scope thesis so that when we talk about "self-ownership," we tend to mean the scope thesis. This is probably because what Nozick and Cohen really wanted to argue about was not self-ownership per se (Nozick, for example, spends surprisingly little space on the idea and never clearly defines it), but on the nature of individual liberty, property rights, and their relation to political authority. Nozick, the libertarian, wants to defend a natural limit on the ability of political authorities to seize property for political purposes, and Cohen, the egalitarian, wants to allow for such authority.

Michael Otsuka, one of the most prominent "left-libertarians" (who attempt to combine the two outlooks, making libertarianism safe for egalitarianism or vice versa), is clear that the debate about self-ownership is really a debate about the scope thesis. In a footnote of one of his key papers on the topic, ${ }^{14}$ referring to Nozick's basic claim about self-ownership, Otsuka writes:

In this passage [on self-ownership] Nozick appears to distinguish a right to reap the benefits of one's labor from a right to self-ownership. In this article I will, if only for ease of exposition, treat a right to reap such benefits as an aspect of a right to self-ownership. 
On the next page and in another footnote, Otsuka ${ }^{15}$ argues that Cohen more or less does the same thing in relation to Nozick. Cohen and Otsuka are probably right that Nozick was indeed interested in something like the scope thesis, but, as I have argued here, the idea of self-ownership is only a part of the larger scope thesis. We can investigate the idea of self-ownership in isolation from the scope thesis; which is just to say that we needn't talk about libertarianism when we talk about self-ownership.

All libertarians care about self-ownership, but it isn't necessarily true that all theorists who care about self-ownership are libertarians. Thinking in terms of the difference between the concept of self-ownership and the scope thesis can help us see this. If we are mostly talking about the scope thesis when we talk about self-ownership, it is worth looking more closely at the concept of self-ownership independently of or antecedently to the scope thesis.

\section{SELF-OWNERSHIP AS PROPERTY}

In his work on self-ownership, Cohen ${ }^{16}$ was very careful to distinguish between the concept of self-ownership and the thesis of self-ownership. The concept, he argued, may be incoherent or malformed, but it cannot be false. The thesis-what the implications of the concept are in social and moral philosophy—may be false, pernicious, or whatever. In the previous section, I made a similar distinction between the concept of self-ownership and what I called the scope thesis. This distinction is not identical with Cohen's, but the overall strategy is similar. To understand self-ownership as a concept, we need to isolate it from its implications. 
I think it is no surprise that self-ownership plays an important role in the normative conceptual toolbox of a variety of liberal thinkers. Cohen, quotes Richard Overton from An Arrow Against All Tyrants, who argues:

To every Individuall in nature is given an individual property by nature, not to be invaded or usurped by any: for everyone as he is himselfe, so he has a self propriety, else could he not be himselfe .. . Every man by nature being a King, Priest and Prophet in his owne naturall circuit and compasse. ${ }^{17}$

Overton, a Leveler during the English Civil War, is expressing a recognizably liberal sentiment. There are similarities in Locke's defense of self-ownership and in Mill's defense of individual sovereignty in On Liberty, where he writes that the individual's "independence is, of right, absolute. Over himself, over his own body and mind, the individual is sovereign.” Arguably, H. L. A. Hart's 18 "equal right to freedom," Warren Quinn's ${ }^{19}$ defense of the authority of individuals as "independent beings," and Judith Thomson's defense of rights to bodily $\operatorname{control}^{20}$ and against trespass ${ }^{21}$ also share many of the features of a concept self-ownership. Thomson's defense of "first property" in the body as a right against trespass is a clear invocation of a concept of self-ownership, though without the scope thesis. Cohen admits that Thomson has developed a conception of self-ownership that, since it does not endorse the scope thesis as I have called it, is not liable to his criticisms. ${ }^{22}$ But, since this is, as he argues, not the same conception of selfownership that libertarians endorse, he rejects it as being "besides the point." 
We will return to this language of sovereignty in Overton and Mill and what it might suggest about how to understand the concept of self-ownership, but the general point is that, given its traditional importance in liberal thought, and what even Cohen ${ }^{23}$ admits is its prima facie attractiveness, there is good reason to take self-ownership seriously as a moral and political concept. To say that self-ownership should be taken seriously in the liberal normative conceptual scheme does not, however, say very much about how we should understand that concept. An important normative political concept like SELF-OWNERSHIP is very likely to be what Gallie ${ }^{24}$ called an "essentially contested concept," for the very reason that, as I argued in Section I, it is difficult to disentangle self-ownership from its implications, such as the scope thesis. One way, to isolate the concept of self-ownership, while evaluating different and competing ways to understand that concept, is to make the well-rehearsed move of distinguishing between the concept of SELF-OWNERSHIP and particular conceptions of self-ownership. ${ }^{25}$

Applying this method, we can distinguish between three distinct conceptions of self-ownership that are often mixed or conflated. Call the first and most straightforward the property conception of SELF-OWNERSHIP. This is the idea that self-ownership is a right or collection of rights that operates like a traditional property right, only over the self. We might call this the "folk conception" of self-ownership since this seems to be what most defenders ${ }^{26}$ as well as opponents ${ }^{27}$ mean by self-ownership. This conception of self-ownership has close affinity with the scope thesis and, hence, with libertarianism or its denial.

The property conception of self-ownership is the dominant one in the literature and there has been substantial ink spilled either defending or opposing it. Nevertheless, 
there are several reasons to be suspicious of this conception of self-ownership. The first is that, as I have already noted, the property conception seems to smuggle in the scope thesis or at least to naturally suggest it. A more basic reason to reject the property conception of self-ownership is that self-ownership seems to be importantly dissimilar to ownership over other goods. Kasper Lippert-Rasmussen ${ }^{28}$ calls one version of this idea the "asymmetry thesis" that the moral importance of ownership rights in external objects is different from the moral importance of self-ownership. This is a denial of the stringency of the scope thesis.

Self-ownership, on whatever conception, will imply, minimally, a right against trespass. ${ }^{29}$ Trespass involves a violation of a boundary that, in many core cases, involves the body. Typical legal examples of trespass include assault, battery, and false imprisonment, all of which are also paradigmatic violations of self-ownership. Judith Thomson $^{30}$ argues that rights against trespass are so important that they "are at the center of the realm of rights." Rights against trespass, though, are not the same as property rights, either in form or in stringency.

When it is conceived as a right of exclusion, self-ownership is naturally connected with property; but features of the right to exclude also suggest some important differences between the concepts of ownership and property. To own something is to have the right to exclude others from it, but ownership in the property sense typically involves more than a right to exclude, and can also include limits on a right to exclude. ${ }^{31}$ Additionally, property in the normal sense typically includes liability rules. ${ }^{32}$ Liability, however, is not a part of the property conception of self-ownership in any of its major variants. ${ }^{33}$ The disanalogy between traditional property rights and self-ownership is 
important in cases both of liability to damages and eminent domain. There is really no analogue to eminent domain in the property conception of self-ownership, and critics ${ }^{34}$ as well as defenders ${ }^{35}$ of self-ownership argue that incorporating liability rules into the idea of self-ownership undermines its distinctiveness as a moral concept.

All of this is to suggest that there is not a natural fit between property rights and self-ownership. Minimally, as Thomson argues, self-ownership should include rights against trespass. These could be understood as property rights, but that is not how they are typically understood by the law or in terms of their moral stringency. Bodily trespass is typically a more serious moral violation than interference against property. Second the idea of property in one's person doesn't seem to capture the idea from Mill that seems to lie at the heart of self-ownership: that "over himself, over his own body and mind, the individual is sovereign." Being able to acquire, use, and exchange property may be a necessary component of individual sovereignty, but it doesn't seem sufficient for it, which is to say that while property may have an important connection to self-ownership, there are disanalogies between our ideas of property and the core idea of self-ownership. Because of this, it is misleading to think of self-ownership as a kind of property right.

\section{SELF-OWNERSHIP AS AUTONOMY}

Many thinkers have rejected the idea of a property right in the self (the property conception of self-ownership) and argued, instead, that self-ownership is really concerned with protecting or enhancing individual autonomy. Call this view the autonomy conception of self-ownership. On the autonomy conception, self-ownership protects basic 
liberties to make decisions and engage in certain actions. For instance, John Christman argues that any plausible conception of self-ownership must be grounded in protection of the liberties that allow individuals to control their lives. ${ }^{36}$ Cohen also alludes to the autonomy conception as being the better way to understand self-ownership. He argues, that "what matters to an agent is not only whether he is subject to the comprehensive concentrated control of a single alien will but whether what he does is subject to his own will." 37

Cécile Fabre argues that Cohen was attracted to what I have called the autonomy conception of self-ownership. ${ }^{38}$ At the limit, this notion of self-ownership is not so much a basic right as it is a goal or ideal with, perhaps, an accompanying right to selfownership that is necessary to protect the pursuit of that goal. Nevertheless, the core idea is that autonomy, not self-ownership is morally important. Defenders of the autonomy conception of self-ownership sometimes argue that the protection of a right to selfownership is necessary to secure the adequate development of full autonomy. Loren Lomasky, for instance, argues that the protection of individual rights, which look very much like self-ownership rights, are necessary to protect the ability of individuals to pursue distinct personal projects. ${ }^{39}$

This conception of self-ownership is appealing for several reasons. First, it avoids the possible conceptual confusion and general awkwardness of thinking about "owning" persons. Insofar as the property conception opens the door for ownership to apply to persons and not just things, this seems to conceptually open the door for slavery. ${ }^{40}$ Many libertarians who endorse the property conception of self-ownership explicitly embrace this conclusion by arguing in favor of a right to sell one's self into slavery. ${ }^{41}$ Second, 
there is an intuitive appeal connecting the idea of autonomy and freedom of selfownership. As Carole Pateman argues, "The consensus among most participants in the [self-ownership] debate is that self-ownership is merely a way of talking about autonomy," and "self-ownership appears uncontroversial and synonymous with autonomy." ${ }^{42}$ Self-ownership, on this view, is merely a stand-in for autonomy. Third, the autonomy conception of self-ownership does not seem committed to the scope thesis and, hence, one can presumably hold something like this conception of self-ownership while remaining agnostic on social questions of private property or acquisition.

Attractive as this conception of self-ownership may seem, it also has several serious problems. The first is conceptual fit. Self-ownership is a threshold concept; either you have it, or you don't. Autonomy is a scalar concept; one can be more or less autonomous. Addicts and the severely mentally disabled, for instance, may not be very autonomous. Nevertheless, they can still be considered self-owners. The mentally disabled and addicts do not lose their basic rights against bodily trespass merely because they have reduced autonomy.

The second is, as with the property conception, a mismatch in the moral severity of violations of autonomy and self-ownership respectively. Swabbing someone's mouth without her consent does not reduce her autonomy, though it is clearly a trespass against her. The trespass isn't wrong because it reduces her autonomy; rather, it's wrong because it represents someone (the swabber) showing disrespect for the right of another to consent or not to bodily interference. Respect is owed because he or she is capable of autonomy. Autonomy, on this view, is the underlying value or interest that supports a right to selfownership, but self-ownership is not simply identical with autonomy; this approach does 
not reduce the right of self-ownership to a consideration of autonomy. Trespassing against a person in one way, while enhancing her autonomy in another way would not necessarily eliminate the wrong of the original trespass. In this way, it looks like the concern with autonomy will not replace self-ownership, but rather explain it.

At this point it is worth taking stock. I have argued that there is a core moral and political concept of self-ownership that plays an important role in a variety of political and moral theories. This concept, however, is not well defined. I have, so far, articulated the most common interpretation, what I have called the property conception of selfownership. I have also articulated another conception of self-ownership that I have called the autonomy conception. In some ways, though, the latter should not be considered a conception of self-ownership at all. Instead, we can think of it as a pseudo- or hypothetical conception of the concept. It is an interpretation of the idea of selfownership, given that the property conception is unsound. On this view, when we talk about "self-ownership," we are really talking about a form of autonomy. To be precise then, the autonomy conception is really something like an error theory of self-ownership that identifies it with the property conception. We can think of the argument as going something like this:

1. SELF-OWNERSHIP can only be understood in the way specified by the property conception.

2. The property conception of SELF-OWNERSHIP is unsound, invalid, or implausible. 
3. Nevertheless, there is some normative concept that defenders of SELFOWNERSHIP are referring to.

4. That concept is best understood as some aspect of AUTONOMY.

If these are the only two conceptions of self-ownership on offer, we are in a bind since both conceptions have serious problems. There is, however, an alternative to both the property and autonomy conceptions of self-ownership, though not one that has been hitherto defended explicitly. I call this the sovereignty conception of self-ownership. These three conceptions and their relationship to the underlying concept is represented in Figure 1.

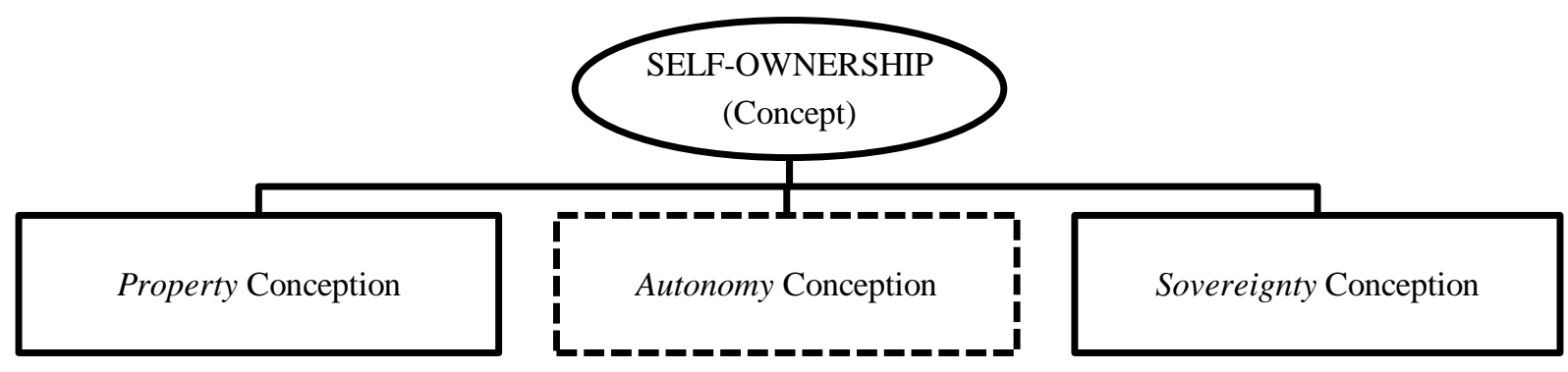

Figure 1. Conceptions of Self-Ownership

\section{SELF-OWNERSHIP AS PERSONAL SOVEREIGNTY}

In this section, I develop a conception of self-ownership as a form of sovereignty rather than property. Instead of thinking of self-ownership as representing a property relation with regard to one's self or as protecting some interest in autonomy, we should instead see it as delineating a sphere of authority that individual's uniquely have with regard to their bodies and actions. In this sense, the individual is sovereign over his or her 
body and actions in the way that a political authority is sovereign over some territory. Without delving too far into the theory of political sovereignty, we can say of individual sovereignty what Mill did, that "in the part which merely concerns himself, his independence is, of right, absolute. Over himself, over his own body and mind, the individual is sovereign."

We can regard the idea of self-ownership in this sense as being something akin to territorial rights over the body. There has been considerable discussion of territorial rights in contemporary political philosophy, ${ }^{43}$ and most of the disputes that revolve around territorial rights are irrelevant to the question here as the analogy between political sovereign territorial rights and individual sovereignty is not exact. One important dispute among territorial theorists that is relevant to the discussion here is whether territorial rights are really a special kind of property rights. ${ }^{44}$ There is no doubt that there are similarities between sovereign rights and property rights as both involve a claim of jurisdictional authority. This is a key feature of all rights, namely that they make the right-holder "small scale sovereign," as Hart described it, over some domain. ${ }^{45}$ The core question is whether sovereign or territorial rights are derived from or reducible to property rights.

I have already explained above why thinking of self-ownership as a property right has problems. Self-ownership as individual sovereignty preserves the aspect of the property conception that might have seemed intuitively appealing, namely its connection to a right of exclusion. On the sovereignty conception, this can be explained in a simpler way as a supreme territorial jurisdiction over one's body and the right to make decisions 
with regard to one's actions. This is the core idea of individual sovereignty. Within one's body, only the individual may decide how the body is used.

This right, however, does not mean that the individual always has full, effective control over one's body. The workings of one's digestive system, for instance, are not subject to the will of the individual directly. This may seem to suggest a disanalogy with territorial jurisdiction, but this is a mistake. Even states that claim absolute power (for example, North Korea or the former Soviet Union) cannot control everything that happens within their territory. They cannot, for instance, make rivers flow in reverse or crops grow when there is no rain. The same is true of individuals and their bodies. One can limit the food one eats in order to lose weight or eat additional protein to gain muscle, but results are not guaranteed. The main point about jurisdiction is that it limits who else has the authority to interfere with one's body.

We can think of this sovereign jurisdictional right as also extending to the idea of basic dominion or self-determination. How and which talents to develop, whether and when to have children, and whom to marry are central freedoms that are related to basic rights that define the individual. The right to make these choices is the right to be selfdetermining in a fundamental sense. Understanding the individual as the supreme authority in these types of decisions explains the importance of consent and shows another reason why the sovereignty conception of self-ownership is superior to the autonomy conception. Consent, or the right to choose is essential in the case of, say, who to marry because only the individuals involved, we think, have the right to decide whether they will pursue a romantic relationship. Who one marries or what talents one 
develops might actually undermine one's autonomy in important ways, however, by taking on certain roles or adopting the discipline of certain practices.

Nevertheless, we might think that it is the interest of autonomy in general that the right to self-ownership protects on the autonomy conception, even if the decisions of an individual in particular cases are autonomy reducing. I have already argued that this is misleading, but it is easy to see if we consider cases of bodily trespass in which the individual didn't know someone trespassed against him, for instance in medical experiments or sexual assaults on unconscious patients. As Arthur Ripstein argues in a similar context, it seems misleading to claim that the wrong in these cases is the lack of respect for autonomy or, for that matter, some violation of property rights. ${ }^{46}$ Instead the wrong is a result of some other person usurping the authority of the individual to decide how his or her body is used. Only the patients' authorization, in the form of consent, can authorize medical interventions. This indicates that it is the sovereign authority that is at stake, not autonomy. It is perhaps no surprise, then, that those who reject self-ownership or argue that what is really at stake is autonomy, for instance, G. A. Cohen ${ }^{47}$ and Cécile Fabre, ${ }^{48}$ have a notoriously hard time explaining why rape and other similar trespasses are wrong. Self-ownership as individual sovereignty, however, explains the wrongness of rape in a simple and elegant way as a trespass and violation of basic jurisdictional rights over the body; it silences the victim's right to exclude others and to say "no." 49

Occupational choice is another clear example. If one chooses to become a teacher, the decision may be prudent, silly, or shortsighted, but it is nevertheless the individual who has authority—uniquely—to make that choice. Even if one enjoys teaching and is well suited for it, it would be an extreme interference with one's sovereign authority, in 
terms of one's self-determination, to be forced to become a teacher. It is no surprise then that occupational choice is often at issue between defenders and opponents of selfownership. ${ }^{50}$ We can see this principle honored in the breach as well since it is only by claiming a higher sovereign authority in emergencies, or for very serious reasons of national defense in the case of a military draft, that legitimate states can argue that individual self-determination rights can be overridden.

The fruits of one's body and self are the clearest examples of resources that an individual should have control over. This doesn't require the scope thesis, but it does mean that individuals will naturally take ideas and the fruit of their labor to be theirs in some sense. We can think of this aspect of self-ownership as a basic liberty right to use one's body and self in ways that one chooses. This idea is backed up by recent developmental psychology. By the age of two or three, children develop complex beliefs about ownership of external objects and their own bodies. ${ }^{51}$ Ideas about who owns what seem to arise out of a conception of bodily ownership and sovereignty, ${ }^{52}$ and this idea seems to be territorial in nature. ${ }^{53}$ Children as young as six years old will apply the idea of ownership to ideas if they believe they are the first to develop those ideas. ${ }^{54}$ All of this suggests that the idea of self-ownership, as it develops psychologically, is connected with drawing boundaries or borders of authority over the body and its fruits. This evidence is consistent with an attenuated version of the property conception of self-ownership, but since it is focused on territorial aspects of the body, it seems more consonant with the sovereignty conception as I have developed it here, suggesting that there are not only good conceptual and philosophical reasons for endorsing the sovereignty conception, but empirical ones as well. 
We are now in a position to articulate the sovereignty conception of self-ownership. As I have described it, we can see that the right to self-ownership as individual sovereignty has three elements:

1. Bodily Jurisdiction - Unique authority over the jurisdiction of one's body

2. Self-Determination-Unique authority over one's actions and choices

3. Consent-The power to authorize access to one's body through consent

The first is the core idea of self-ownership. Even slaves, who were considered property and, hence, not self-owners in the sense of the property conception, often retained some rights to bodily jurisdiction. ${ }^{55}$ Children, who are not fully autonomous and who may lack full rights of self-determination and consent are still considered self-owners with respect to bodily jurisdiction. Indeed, trespasses against the bodies of children, especially sexual ones, are considered more morally serious than those against adults.

The second feature, self-determination, is a version of the first that applies specifically to actions and choices rather than to the body. Children as early as six years old begin to see ideas and choices as "theirs" in some important sense and as they become more and more independent, their sovereignty in this area is extended. Again, this feature does not claim or require that individuals can direct all of their actions or choices effectively or that they are autonomous in that they only respond to laws or norms that they give themselves. Rather the claim is signaled by the uniqueness of the authority. The claim is that only the individual has the authority to decide what he or she will do or choose. This authority can be given to others in certain circumstances by 
exercising the power of consent, which requires self-determination to generate its morally transformative power.

As I have already suggested, self-ownership as individual sovereignty must have all three of these features for an individual to be fully sovereign. Children and those with severe cognitive disorders may lack full self-determination and, hence, full powers to consent. One of the key differences between this and other conceptions of self-ownership, however, is that even in those cases, individuals will still retain their right to bodily jurisdiction. In this way, we should think of self-ownership as a structure that one builds as one matures and gains increasing independence but that, nevertheless, has a firm foundation in bodily jurisdiction that cannot be undermined.

The sovereignty conception of self-ownership as I have sketched it is neither a highly revisionary account of self-ownership, nor a pseudo-conception like the autonomy conception. Instead, the sovereignty conception picks out the core idea at the heart of self-ownership that has animated so many thinkers. To be a self-owner in the sense advanced here is to have the right to exclude trespasses and to lay claims to the basic resources of the body and mind. This does not imply, however, anything about the relationship between the self-owner and external property. There are, of course, similarities between sovereignty and property rights. This, I want to suggest, is not because sovereignty rights are property rights (as some argue), but rather because property rights are shadowy projections of a kind of sovereignty. Self-ownership is, first and foremost, about what basic rights define individual personhood, not about who gets what stuff. 


\section{CONCLUSION}

To sum up, the argument so far is:

1. SELF-OWNERSHIP is an important moral and political concept.

2. There are at least three conceptions of SELF-OWNERSHIP that differ considerably.

3. The most plausible conception is what I call the sovereignty conception of SELFOWNERSHIP.

4. This conception is both a genuine conception of SELF-OWNERSHIP and morally attractive in its own right.

5. There are good reasons to embrace SELF-OWNERSHIP as the sovereignty conception in most plausible and attractive moral and political theories.

The last two of these claims have not been defended explicitly but are implicit in the defense of the sovereignty conception from the previous section.

The benefits of adopting and the costs of eliminating self-ownership from our moral and political conceptual scheme, give us prima facie reason to endorse the idea insofar as doing so does not do violence to many of our other strongly held political and moral views. The property conception of self-ownership fails this test. The sovereignty conception, however, doesn’t impose many costs. It doesn't settle most or many questions in moral and political philosophy but does do important work in clarifying key ideas. Because of this, self-ownership is a conceptual bargain. By admitting it into our moral conceptual scheme we can easily explain the wrongness of grievous violations 
such as rape and slavery, without thereby being committed to the strong property rights as embodied in the scope thesis.

The contemporary flight from self-ownership is largely a response to its assumed implications: libertarian property rights and a severely restricted scope for government action. While accepting that self-ownership does create a basis for core liberal rights that are incompatible with unlimited government power, the exact nature of those rights and the proper scope of government are not directly settled by the idea of self-ownership alone. In the liberal house, there are many mansions. Most versions of liberalism are compatible with self-ownership rightly understood.

Accepting self-ownership is not without consequences, however. It is incompatible with certain forms of illiberal egalitarianism, paternalism, and any unlimited system of political authority. It may also be at odds with certain forms of moral consequentialism. Self-ownership does create an important space for individuals to live their lives largely on their own terms and to resist, at least some of, the wants and demands of others. This right reflects the nature of human beings as separate moral agents in the most important sense: "separate" in that each has a life to live that cannot be sacrificed or weighed against others, and "moral" in the sense that each person is expected to make and be responsible for his or her liberty and its consequences.

Moral and political theorists should welcome self-ownership in from the cold. The original charges against it were false, confused, or based on a faulty understanding of the idea. Once it is readmitted into the good graces of moral and political theory, selfownership has an important and salutary role to play. 
As a moral-political concept, self-ownership earns its keep at a low cost. Selfownership, in the sovereignty conception I have defended here, identifies and articulates two key aspects of our moral personality: having dominion over ourselves - the right to exclude others and the liberty to use our bodies and ourselves as we deem fit. Whatever else it means to be treated equally as a full-fledged member of the moral community; it must mean at least this. Basic rights to noninterference and against trespass, however, are not property rights. We should care about self-ownership because it is at the center of any plausible conception of rights. The basic right against trespass and the right to be one's own master have been at the heart of many of the most important legal and moral struggles throughout history. We only have to look to those who have been denied this right to understand why. As the quote from Abraham Lincoln at the beginning of this essay argues, "no man is good enough to govern another man without that other's consent." This idea, which I have argued is at the core of self-ownership, is not only, as Lincoln said, the "sheet anchor" of American republicanism, but at the beating heart of any conception of a society of free and equal individuals.

Philosophy, Chapman University 
${ }^{1}$ Thomas Nagel, "Libertarianism without Foundations," The Yale Law Journal 85, no. 1 (1975): 136-49; Samuel Freeman, “Illiberal Libertarians: Why Libertarianism Is Not a Liberal View," Philosophy and Public Affairs 30, no. 2 (2001): 105-51; Liam Murphy and Thomas Nagel, The Myth of Ownership: Taxes and Justice (Oxford; New York: Oxford University Press, 2002.)

${ }^{2}$ G. A. Cohen, Self-Ownership, Freedom, and Equality (Cambridge: Cambridge University Press, 1995); Kasper Lippert-Rasmussen, “Against Self-Ownership: There Are No Fact-Insensitive Ownership Rights over One's Body," Philosophy and Public Affairs 36, no. 1 (2008): 86-118; Cecile Fabre, Whose Body Is It Anyway? Justice and the Integrity of the Person (Oxford, New York: Oxford University Press, 2008).

${ }^{3}$ John Rawls, A Theory of Justice, rev. ed. (Cambridge, MA: Belknap Press, 1999).

${ }^{4}$ Joseph Raz, The Morality of Freedom (Oxford: Clarendon Press, 1986); Steven Wall, Liberalism, Perfectionism and Restraint (Cambridge: Cambridge University Press, 1998).

${ }^{5}$ Gerald Gaus, Justificatory Liberalism: An Essay on Epistemology and Political Theory (New York: Oxford University Press, 1996); John Tomasi, Free Market Fairness (Princeton, NJ: Princeton University Press, 2012); Gerald Gaus, The Order of Public Reason: A Theory of Freedom and Morality in a Diverse and Bounded World (New York: Cambridge University Press, 2011).

${ }^{6}$ Hillel Steiner, An Essay on Rights (Cambridge, MA: Blackwell, 1994); Philippe Van Parijs, Real Freedom for All: What (If Anything) Can Justify Capitalism (Oxford; 
New York: Clarendon Press, 1998); Michael Otsuka, Libertarianism without Inequality (New York: Oxford University Press, 2003); Peter Vallentyne, Hillel Steiner, and Michael Otsuka. "Why Left-Libertarianism Is Not Incoherent, Indeterminate, or Irrelevant: A Reply to Fried,” Philosophy and Public Affairs 33, no. 2 (2005): 201-15.

${ }^{7}$ Robert Nozick, Anarchy, State, and Utopia (New York: Basic Books, 1974); Murray N. Rothbard, Power and Market: Government and the Economy, 2nd ed. (Kansas City, MO: Sheed Andrews and McMeel, 1977); Eric Mack, "Self-Ownership and the Right of Property,” Monist 73, no. 4 (1990): 519-43; Mack, “The Self-Ownership Proviso: A New and Improved Lockean Proviso," Social Philosophy and Policy 12, no. 1 (1995): 186-218. https://doi.org/10.1017/S0265052500004611; Loren Lomasky, Persons, Rights, and the Moral Community (New York: Oxford University Press, 1990).

${ }^{8}$ Judith Jarvis Thomson, "Some Ruminations on Rights," Arizona Law Review 19 (1977): 45-60; Samuel Freeman, "Illiberal Libertarians: Why Libertarianism Is Not a Liberal View," Philosophy and Public Affairs 30, no 2, (2002): 105-51; Barbara H. Fried, The Progressive Assault on Laissez Faire: Robert Hale and the First Law and Economics Movement (Cambridge, MA: Harvard University Press, 2001).

${ }^{9}$ G. A. Cohen, Self-Ownership, Freedom, and Equality (Cambridge: Cambridge University Press, 1995), 213.

${ }^{10}$ G. A. Cohen, "Self-Ownership, World-Ownership, and Equality,” in Justice and Equality Here and Now, ed. Frank Lucash (Ithaca, NY: Cornell University Press, 1986), 109. 
${ }^{11}$ For example, see Bas van der Vossen, "Imposing Duties and Original Appropriation," Journal of Political Philosophy 23, no. 1 (2014): 64-85.

12 Thomson, "Some Ruminations on Rights."

13 Thanks to Mark Budolfson for pointing this out to me.

${ }^{14}$ Michael Otsuka, "Self-Ownership and Equality: A Lockean Reconciliation," Philosophy and Public Affairs 27, no. 1 (1998): 66, n. 4.

15 Otsuka, "Self-Ownership and Equality: A Lockean Reconciliation,” 67, n. 7.

${ }^{16}$ Cohen, Self-Ownership, Freedom, and Equality, chap. 9.

${ }^{17}$ Cohen, Self-Ownership, Freedom, and Equality, 209.

${ }^{18}$ H. L. A. Hart, “Are There Any Natural Rights?” Philosophical Review 64, no. 2 (1955): 175-91.

${ }^{19}$ Warren Quinn, “Actions, Intentions, and Consequences: The Doctrine of Doing and Allowing," Philosophical Review 98, no. 3 (1989): 287-312.

${ }^{20}$ Judith Jarvis Thomson, “A Defense of Abortion,” Philosophy and Public Affairs 1, no. 1 (1971): 47-66.

21 Thomson, The Realm of Rights (Cambridge, MA: Harvard University Press).

${ }^{22}$ Cohen, Self-Ownership, Freedom, and Equality, 213 n. 7.

${ }^{23}$ Ibid., 92.

${ }^{24}$ W. B. Gallie, "Essentially Contested Concepts," Proceedings of the Aristotelian Society, New Series 56 (1956): 167-98.

${ }^{25}$ Rawls, A Theory of Justice, 8-9. 
${ }^{26}$ Rothbard, Power and Market: Government and the Economy; Jan Narveson, The Libertarian Idea (Philadelphia: Temple University Press, 1988). Mack, "SelfOwnership and the Right of Property": 519-43; Steiner, An Essay on Rights; Otsuka, "Self-Ownership and Equality, 65-92.Otsuka, Libertarianism without Inequality; Vallentyne, Steiner, and Otsuka, "Why Left-Libertarianism Is Not Incoherent, Indeterminate, or Irrelevant: A Reply to Fried."

${ }^{27}$ Richard Arneson, “Lockean Self-Ownership: Towards a Demolition,” Political Studies 39, no. 1 (1991): 36-54. https://doi.org/10.1111/j.1467-9248.1991.tb00580.x; Cohen, "Self-Ownership, World-Ownership, and Equality”; Peter Railton, "Locke, Stock, and Peril: Natural Property Rights, Pollution, and Risk," in Facts, Values, and Norms (Cambridge: Cambridge University Press, 2003), 187-225; Cécile Fabre, Whose Body Is It Anyway? Justice and the Integrity of the Person (Oxford; New York: Oxford University Press, 2008); David Sobel, "Backing Away from Libertarian Self-Ownership"; Sobel, "Self-Ownership and the Conflation Problem," in Oxford Studies in Normative Ethics, Vol. 3, ed. Mark Timmons (New York: Oxford University Press, 2014), 98-122.

${ }^{28}$ Kasper Lippert-Rasmussen, “Against Self-Ownership: There Are No FactInsensitive Ownership Rights over One's Body," Philosophy and Public Affairs 36, no. 1 (2008): 88 .

${ }^{29}$ Thomson, The Realm of Rights. chap. 8.

${ }^{30}$ Ibid., 212.

${ }^{31}$ Harold Demsetz, "Toward a Theory of Property Rights," The American 
Economic Review 57, no. 2 (1967): 347-59; Jeremy Waldron, 1988. The Right to Private Property (Oxford: Clarendon Press, 1988); David Schmidtz, “The Institution of Property," in Person, Polis, Planet: Essays in Applied Philosophy (Oxford: Oxford University Press, 2008), 193-210.

32 Demsetz, "Toward a Theory of Property Rights"; Demsetz, "When Does the Rule of Liability Matter?” The Journal of Legal Studies 1, no. 1 (1972): 13-28. https://doi.org/10.1086/467477; Guido Calabresi and A. Douglas Melamed, "Property Rules, Liability Rules, and Inalienability: One View of the Cathedral," Harvard Law Review 85, no. 6 (1972): 1089-1128. https://doi.org/10.2307/1340059).

${ }^{33}$ I thank Keith Hankins for pointing this out to me.

${ }^{34}$ Railton, "Locke, Stock, and Peril: Natural Property Rights, Pollution, and Risk"; Sobel, "Backing Away from Libertarian Self-Ownership."

${ }^{35}$ Eric Mack, "Elbow Room for Rights," in Oxford Studies in Political Philosophy, ed. David Sobel, Peter Vallentyne, and Steven Wall, Vol. 1 (New York: Oxford University Press, 2015): 194-221.

${ }^{36}$ John Christman, "Self-Ownership, Equality, and the Structure of Property Rights," Political Theory 19, no. 1 (1991): 28-46.

https://doi.org/10.1177/0090591791019001003.

${ }^{37}$ Cohen, Self-Ownership, Freedom, and Equality, 235.

${ }^{38}$ Fabre, Whose Body Is It Anyway? Justice and the Integrity of the Person, 3 n. 3. 
${ }^{39}$ Lomasky, Persons, Rights, and the Moral Community.

${ }^{40}$ Ingram, A Political Theory of Rights.

41 Vallentyne, Steiner, and Otsuka, "Why Left-Libertarianism Is Not Incoherent, Indeterminate, or Irrelevant: A Reply to Fried"; Danny Frederick, “The Possibility of Contractual Slavery," Philosophical Quarterly 66, no. 262 (2016): 47-64.

${ }^{42}$ Pateman, "Self-Ownership and Property in the Person: Democratization and a Tale of Two Concepts," 20, 24.

43 Lea Ypi, “A Permissive Theory of Territorial Rights," European Journal of Philosophy 22, no. 2 (2012): 288-312. https://doi.org/10.1111/j.14680378.2011.00506.x; Ypi, “Territorial Rights and Exclusion,” Philosophy Compass 8, no. 3 (2013): 241-53. https://doi.org/10.1111/phc3.12018; Ypi, Boundaries of Authority (New York, NY: Oxford University Press, 2016).

${ }^{44}$ On this point see the debate between Cara Nine ("A Lockean Theory of Territory," Political Studies 56, no. 1 (2007): 148-65. https://doi.org/10.1111/j.14679248.2007.00687.x; Nine, “Territory Is Not Derived from Property: A Response to Steiner," Political Studies 56, no. 4 (2008): 957-63. https://doi.org/10.1111/j.14679248.2008.00765.x) and Hillel Steiner ("May Lockean Doughnuts Have Holes? The Geometry of Territorial Jurisdiction: A Response to Nine," Political Studies 56, no. 4 (2008): 949-56. https://doi.org/10.1111/j.1467-9248.2008.00764.x).

${ }^{45}$ H. L. A. Hart, Essays on Bentham: Jurisprudence and Political Theory (Oxford: Oxford University Press, 1982), 183.

${ }^{46}$ Arthur Ripstein, "Beyond the Harm Principle," Philosophy and Public Affairs 34, no. 3 (2006): 227. 
${ }^{47}$ Cohen, Self-Ownership, Freedom, and Equality, 224.

${ }^{48}$ Fabre, Whose Body Is It Anyway? Justice and the Integrity of the

Person, 118-20.

${ }^{49}$ This understanding of the rights of bodily integrity in terms of self-ownership, especially for women, also has a basis in the development of the law. Women's rights correlate with the recognition of women as self-owners in the law (Rick Geddes and Dean Lueck, “The Gains from Self-Ownership and the Expansion of Women's Rights," The American Economic Review 92, no. 4 [2002]: 1079-92).

${ }^{50}$ G. A. Cohen, Rescuing Justice and Equality (Cambridge, MA: Harvard University Press, 2008), 205-14; John Thrasher and Keith Hankins, "When Justice Demands Inequality,” Journal of Moral Philosophy 12, no. 2 (2015): 172-94.

${ }^{51}$ Karen R. Neary and Ori Friedman, "Young Children Give Priority to Ownership When Judging Who Should Use an Object," Child Development 85, no. 1 (2014): 326-37. https://doi.org/10.1111/cdev.12120.

52 Julia Van de Vondervoort, Paul Meinz, and Ori Friedman, “Children’s Judgments about Ownership Rights and Body Rights: Evidence for a Common Basis," Journal of Experimental Child Psychology 155 (2017): 1-11. https://doi.org/10.1016/j.jecp.2016.10.007.

${ }^{53}$ Maykel Verkuyten, Jellie Sierksma, and Jochem Thijs, “First Arrival and Owning the Land: How Children Reason about Ownership of Territory," Journal of Environmental Psychology 41 (2015): 58-64.

https://doi.org/10.1016/j.jenvp.2014.11.007. 
${ }^{54}$ Alex Shaw, Vivian Li, and Kristina R. Olson, “Children Apply Principles of Physical Ownership to Ideas," Cognitive Science 36, no. 8 (2012): 1383-1403. https://doi.org/10.1111/j.1551-6709.2012.01265.x.

55 This was largely not true with regards to African slaves in the American south, but it was generally true with regards to slaves in Greece, Rome, and the rest of the world. 